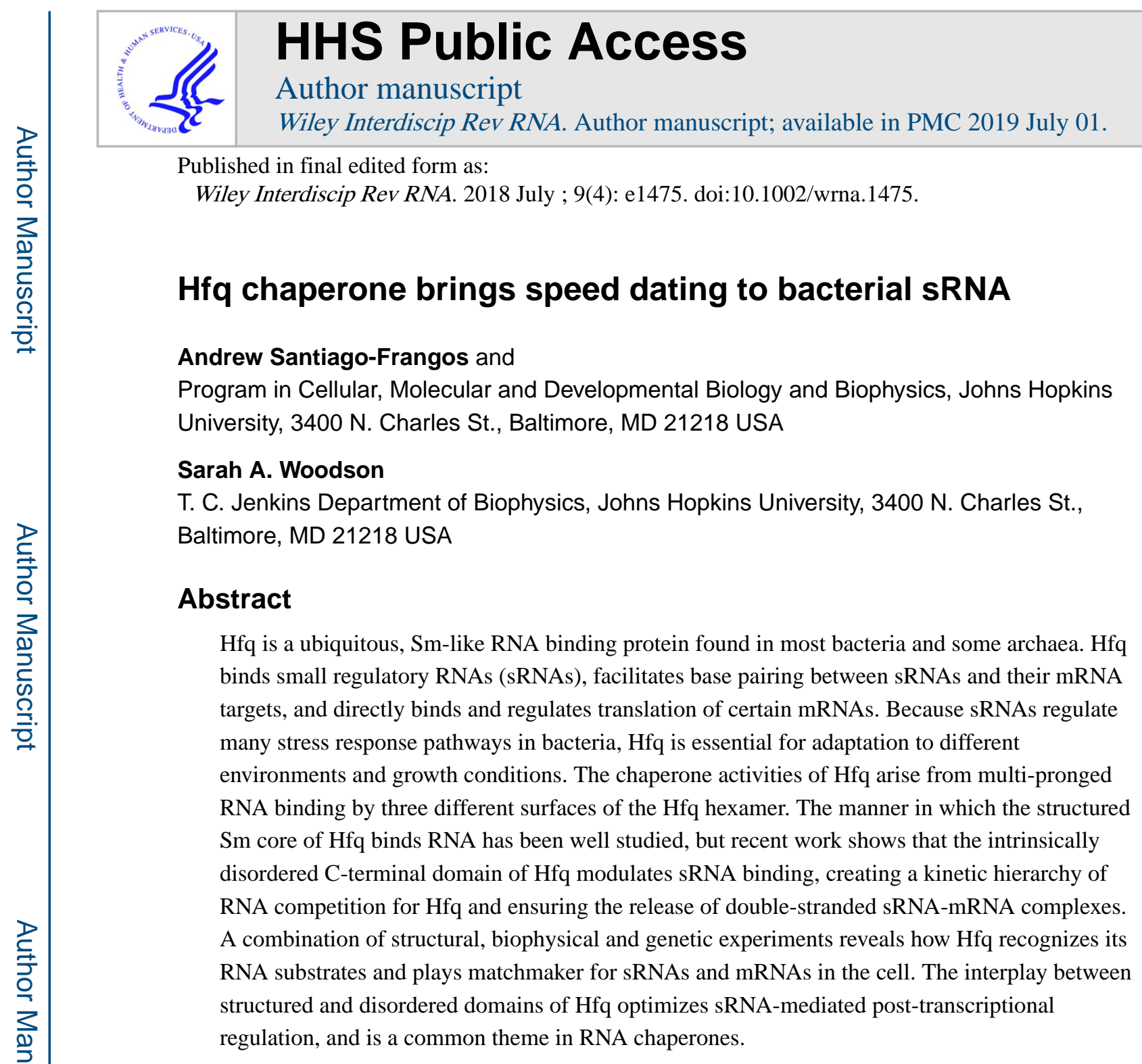

\title{
Graphical/Visual Abstract
}




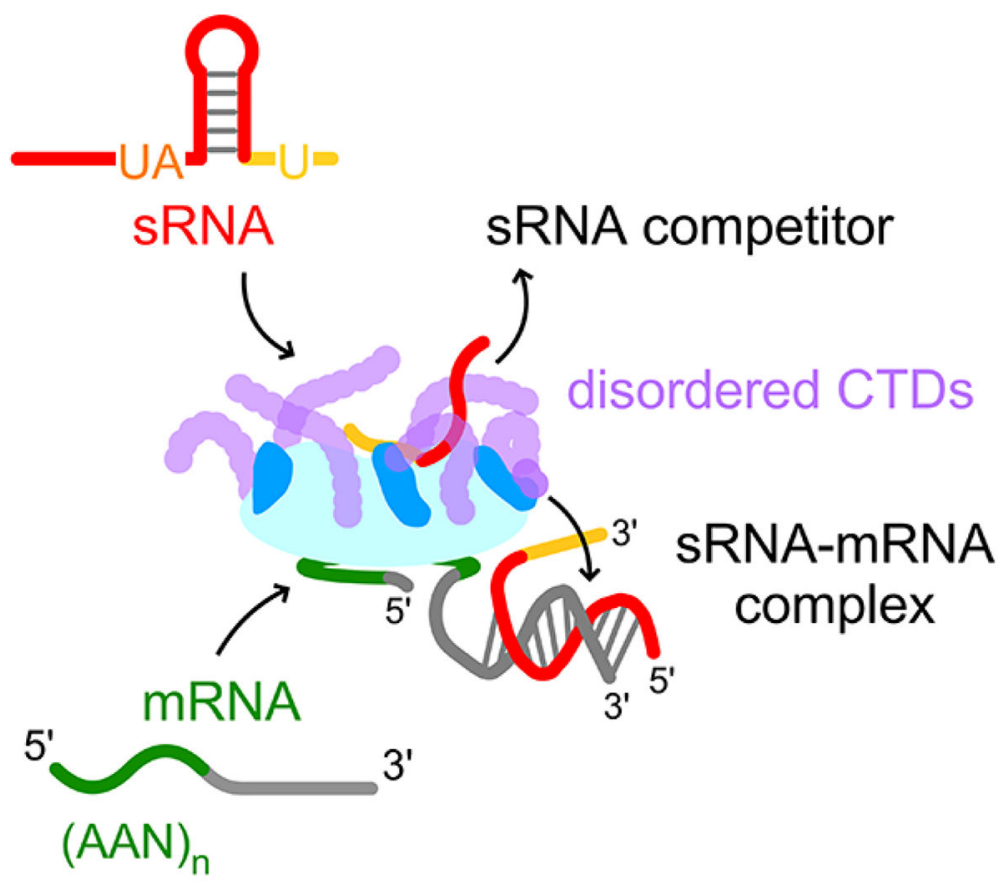

The chaperone Hfq accelerates match-making between small regulatory RNA and mRNA in bacteria. The Hfq core (cyan) binds U and A rich RNA motifs, recruiting complementary strands to arginine patches (blue). Disordered C-terminal domains (violet) sweep RNA from the core, quickly cycling prospective sRNA-mRNA pairs.

\section{Introduction}

Originally identified as a $\underline{H}$ ost Factor required for the replication of bacteriophage $\underline{Q} \beta$ in Escherichia coli (1), Hfq is a member of the Sm/Lsm family of RNA binding proteins present in the majority of sequenced bacteria (2-4). Like eukaryotic and archaeal Sm/Lsm proteins, Hfq plays several roles in bacterial RNA metabolism. These roles include destabilization of mRNA by promoting their polyadenylation $(5,6)$, stabilization of small regulatory RNA (sRNA) against degradation (7-9), facilitating sRNA-mRNA base pairing $(8,10)$ in an ATP-independent manner $(11)$, and stimulation of sRNA and mRNA turnover by RNase E cleavage $(9,12,13)$. Hfq can also directly bind certain mRNAs and regulate their translation (14-17). Hfq accomplishes these varied functions by using different surfaces to simultaneously recognize the sequence motifs and structural features of its target RNAs. This multi-faceted RNA recognition creates an adaptable and dynamic chaperone for RNA-dependent regulation.

Hfq is best known for its function in post-transcriptional gene regulation by sRNA. sRNAs range in size from 37-500 nt (18), and can stimulate or inhibit mRNA translation through a variety of mechanisms (Box 1). Many sRNAs act by base pairing with a complementary sequence in the target mRNA, either sequestering the ribosome binding site (RBS) (19) or 
rendering it more accessible for translation $(20,21)$. In E. coli and many other bacteria, Hfq accelerates and stabilizes sRNA-mRNA base pairing $(8,10,21)$.

\section{Box 1}

\section{Mechanisms of SRNA regulation}

Positive regulation involves the annealing of an sRNA to the $5^{\prime}$ end of the mRNA (22), generally remodelling inhibitory RNA structures around the ribosome binding site (RBS) to expose the RBS more for translation $(23,24)$. Alternatively, the sRNA may anneal to and sequester ribonuclease cleavage sites on the mRNA (25). Negative regulation occurs when the sRNA anneals to or around the RBS in a manner that inhibits binding of the ribosome (26). In some cases the annealed sRNA directly targets the mRNA for degradation by RNase $\mathrm{E}(9,12,13)$. In yet other examples, an sRNA indirectly regulates gene expression as a decoy for another sRNA or a sponge for an RNA binding protein (27).

Bacterial sRNAs often regulate several different mRNAs, and an mRNA may be targeted by more than one sRNA (18). These overlapping regulatory interactions may synergistically act towards a similar physiological outcome, or could antagonize each other. Since RNAs are typically in competition for access to $\operatorname{Hfq}(28,29)$, a bacterium's response to a given signal is affected by the current cellular milieu of Hfq-dependent sRNAs and mRNAs, and the ability of each RNA to compete against the others. Consequently, bacterial non-coding RNAs and Hfq variants may have co-evolved in bacterial lineages (30), so that specific regulatory pathways are prioritized over others. For example the appearance of a long Hfq C-terminal domain is coincident with the expansion of the sRNA repertoire in Enterobacteriaceae (30), and the establishment of two classes of sRNAs that compete for Hfq with different efficiencies $(31,33)$.

One challenge in understanding Hfq-mediated regulation is that the RNA substrates vary in size, structure, and sequence motif combinations. This diversity of RNA ligands contrasts with the defined nature of guide RNAs in other RNA silencing systems such as miRNA/ Argonaute and CRISPR-Cas (34). The highly varied nature of Hfq's RNA substrates is mirrored in the broad scope of its proposed protein partners, which have a variety of enzymatic functions (35). Thus, Hfq must be able to flexibly interact with a range of protein and RNA partners, while retaining selectivity for its proper substrates.

The biological functions of Hfq, its interactions with other nucleic acids and proteins in the cell, and newly identified modes of Hfq- and sRNA-mediated posttranscriptional regulation have been recently reviewed elsewhere (36-38). Here, we provide biophysical and biochemical perspectives on how sRNA and mRNA compete for binding to Hfq, how Hfq discriminates between different RNA substrates, and how Hfq facilitates the annealing of complementary RNA strands. Although most studies have used E. coli Hfq, where possible we discuss the results for bacterial and archaeal homologs. 


\section{RNA recognition by the Sm core}

The Sm domain of Hfq assembles into a stable, homo-hexameric ring with sequence-specific binding surfaces on either face (Figure 1). Hfq-dependent sRNAs bind Hfq by interacting with its proximal pore, via their $\rho$-independent terminators that end with 4-6 uridines. By contrast, the distal face of Hfq recognizes an A-rich motif (46) that is often present in mRNA targets of Hfq and sRNA regulation $(23,24)$, and in Class II sRNAs (see Box 2 for sRNA definitions). These motifs enable Hfq to recognize its substrates, although the sequences and secondary structures of individual sRNAs and mRNAs vary enormously. All RNA substrates are thought to make additional stabilizing contacts with basic, arginine-rich patches found on the outer rim of the Hfq hexamer (47-51). It is at these basic rim patches where the sRNA-mRNA pair is annealed $(39,52)$. Finally, the structured core of Hfq is flanked by disordered N-terminal and C-terminal domains (NTDs and CTDs) $(53,54)$ (Figure 1A), which in some cases either bind RNA $(45,55)$ or compete for RNA-protein interactions on the core $(32,40)$. As discussed below, these disordered regions modulate the RNA binding properties of $E$. coli Hfq, and convert Hfq from an RNA binding protein into a dynamic RNA chaperone.

\section{Box 2}

\section{sRNA Class definitions}

E. coli sRNAs have been divided into two groups based on how they bind Hfq (31). The predominant group of sRNAs, Class I, binds to the Hfq proximal pore via a singlestranded U-rich $3^{\prime}$ end and to the Hfq rim via a combined A/U-rich single-stranded region followed by a stem-loop $(31,48,49)$. The targets of Class I sRNAs frequently contain (AAN)x motifs and bind the distal face of Hfq (23). Class II sRNAs interact with the proximal pore, but also bind to the distal face via $5^{\prime}(\mathrm{AAN})_{\mathrm{x}}$ motifs $(31,33)$. The targets of Class II sRNAs are U-rich and interact with the rim of Hfq (31). While the accumulation of Class I sRNAs depends on residues on the rim of Hfq, Class II sRNA accumulation relies on the distal face (31).

\section{Proximal Face}

The proximal face contains a conserved, sequence-specific interaction site for U-rich singlestranded RNA (ssRNA). A deep channel around the proximal inner pore of the Hfq ring binds single-stranded uridines (Figure 1B) (56), with each monomer recognizing a single uridine base $(10,56)$. A slight selectivity for a terminal $3^{\prime}$-hydroxyl group is observed in Enterobacteriaceae $(57,58)$, but not in some Listeriaceae (59). There is no evidence that the RNA threads through the narrow central pore of the hexamer. Specificity for this U-rich RNA motif at the sRNA $3^{\prime}$ end is highly conserved across all bacteria $(56,59,60)$ and archaea (55), and is similar to the binding site for eukaryotic and archaeal Sm proteins (61, 62). The analogous surface of the Lsm2-8 complex recognizes a very similar site in U6 snRNA, leading to the suggestion that the proximal face of the Sm ring is an ancient protein domain that recognizes RNA terminators and ssRNA $(63,64)$. 


\section{Distal face}

The distal face of Hfq recognizes A-rich ssRNA (46). In mRNAs this A-rich site is typically found $5^{\prime}$ to the sRNA-targeted region $(65,66)$. Hfq's from Proteobacteria typically bind a triplet $(\mathrm{AAN})_{\mathrm{X}}$ motif, with one triplet per monomer, in which $\mathrm{A}$ is adenine and $\mathrm{N}$ is any nucleotide $(44,46,67)$ (Figure $1 \mathrm{C})$. The discovery of this additional binding surface explained why Hfq could bind either A or U-rich RNA (68), and why the A-rich recognition sequence was generally longer than the U-rich site (69). RNAs that bind Hfq's distal face typically possess $2-4$ AAN repeats $(65,66)$, although 6 repeats ( 18 nucleotides) can be accommodated on a single hexamer. The distal face residues involved in RNA contacts are well conserved within Proteobacteria, whereas Firmicute Hfqs interact with two nucleotides per monomer, or a total of 12 nucleotides for the full hexamer. Crystallography and tryptophan quenching experiments suggest that $S$. aureus, B. subtilis and L. monocytogenes Hfq bind an $(\mathrm{AN})_{\mathrm{x}}$ motif, in which the second nucleotide makes non-sequence-specific $\mathrm{H}$ bonding and stacking interactions with the protein $(59,67,70,71)$. Finally, some archaeal Hfq's possess diverged distal faces that no longer recognize adenine $(55,72)$. This loss in binding is thought to be due to mutations that cause i) steric occlusion of the binding pockets, ii) an absence of necessary polar contacts and iii) an increase in the negative potential of the distal face $(55,72)$.

\section{Lateral rim}

The discovery of sequence-specific RNA binding sites on the proximal and distal faces revealed how a single Hfq hexamer could bring sRNA and mRNA together, but not how Hfq might position an sRNA to pair with a complementary target. It was also unclear how Hfq protects the $5^{\prime}$ ends of sRNAs from ribonuclease digestion, if sRNAs are only anchored to the proximal pore of Hfq by their $3^{\prime}$ ends $(73,74)$. These questions were answered by the discovery that the lateral rim of the Hfq hexamer interacts with the "bodies" of sRNAs (48, 49) (Figure 1B, D). Moreover, Hfq's RNA chaperone activity was found to crucially depend on the number of arginines in basic patches on the lateral rim formed by each subunit (39, 48) (blue in Figure 1B). E. coli Hfq lacking one or more rim arginines per subunit binds sRNA and mRNA through proximal and distal face contacts, but is unable to promote annealing in vitro and is less active in sRNA regulation in vivo (39). Additionally, the annealing activities of Hfqs from the Proteobacterium Pseudomonas aeruginosa and the Firmicutes Listeria monocytogenes, Bacillus subtilis and Staphylococcus aureus, correlate with the number of arginines in the basic patch (52).

In vivo, sRNA-Hfq rim interactions were particularly important for the stabilization and accumulation of Class I sRNAs (31). The proximal side of the rim of E. coli Hfq is important for binding single-stranded A/U-rich motifs in sRNAs (Figure 1D) $(31,48,49,65)$ and U-rich loops in mRNAs (51). Discrimination against cytosine in preference for uracil is supported by recent structural data of Hfqs from E. coli and Aquifex aeolicus (45, 75). Additionally, there is evidence that the rim of $E$. coli Hfq interacts with dsRNAs and dsDNA $(32,40)$, indicating how stems in sRNAs may be bound (49).

In Proteobacteria, Thermotogae, Aquificae and Euryarchaeota, the rim of the Hfq hexamer tends to be strongly electropositive $(57,72,75-77)$, with a cluster of arginines and lysines

Wiley Interdiscip Rev RNA. Author manuscript; available in PMC 2019 July 01. 
positioned along a groove that connects the proximal and distal sides of the Sm ring. For example, the rim of E. coli Hfq contains a patch of 3 arginines and a nearby lysine (Figure 1D). Like the distal face, however, residues on the rim of Hfq have diverged in Firmicutes and Proteobacteria. In Firmicutes, the rim of the hexamer is generally neutral (56), with the mildly basic rim of $L$. monocytogenes Hfq being an exception (59). While Hfqs from cyanobacteria possess several basic residues on the rim (78), these residues are distributed more sparsely than basic residues in $E$. coli Hfq. Some archaeal Hfqs contain an extensive "strip" of basic residues, running from the proximal edge to the distal edge of the rim (72). It is currently unknown whether the basic rim residues of cyanobacterial and archaeal Hfqs participate in RNA binding.

\section{Chaperone cycle of $\mathrm{Hfq}$}

Its similarity to Lsm proteins (79), role in phage $\mathrm{Q} \beta$ replication (80), and the direct demonstration that Hfq forms stable ternary complexes with sRNA and mRNA suggested that an important function of Hfq is to facilitate sRNA-mRNA interactions $(8,10)$. This was followed by the demonstration that $E$. coli $\mathrm{Hfq}$ speeds sRNA-mRNA base pairing in vitro $(21,81)$, through RNA interactions with the basic patch on the rim (39). As a chaperone for sRNA-mRNA interactions, Hfq must bind a complementary pair of RNAs, accelerate base pairing, and release the annealed duplex to begin the cycle anew (Figure 2). A panoply of recent in vivo and in vitro studies has started to reveal how Hfq overcomes multiple barriers that limit the efficiency and specificity of sRNA-mRNA annealing in vivo. As explained below, these barriers include electrostatic and entropic costs for nucleating RNA double helices (82), self-structure that may mask the complementary region in either RNA, and the marginal stability of some sRNA-mRNA pairs. Recent work is also shedding light on how Hfq can form stable complexes with its RNA substrates, while permitting rapid and dynamic exchange of non-cognate RNAs.

\section{sRNA-mRNA complex stabilization}

The $5^{\prime}$ end of an sRNA target binding site is often called the "seed region" because it is most important for target recognition (86). The seed regions of sRNAs in E. coli and other enteric $\gamma$-proteobacteria are typically less than 10 nucleotides in length and imperfectly complementary to the target mRNA (87-89), leading to poor stability of cognate duplexes and small differences between cognate and non-cognate interactions. E. coli Hfq circumvents the former by creating long-lived ternary complexes that reinforce otherwise thermodynamically unstable sRNA-mRNA duplexes, enabling the sRNA to complete its regulatory activity $(24,90,91)$. The thermodynamic stability of the RyhB-sodB mRNA duplex was shown to correlate exponentially with the strength of sRNA regulation (92). Hfq may also amplify the difference between cognate and non-cognate pairs, through their competition for the same RNA binding surface of Hfq. In other words, annealing between two RNAs in the presence of Hfq no longer relies simply on their sequence complementarity, but also on the complementary disposition of their Hfq binding sites. 


\section{RNA restructuring}

Another way that Hfq can facilitate sRNA-mRNA binding is by refolding one or both RNAs. The complementary regions of many sRNAs and their mRNA targets are partially sequestered in secondary or tertiary structure, inhibiting their binding to each other. Structure probing revealed that $E$. coli Hfq generally restructures both bound sRNAs and mRNAs (10, 93-99), such that the complementary seed and target regions are made more accessible or amenable to annealing. Restructuring can occur through transient non-specific interactions with Hfq, as postulated for other RNA binding proteins with chaperone activity $(100,101)$, or through specific distortion of the RNA by Hfq (97). Restructuring might explain why some long RNAs bind Hfq more slowly $\left(\sim 10^{6} \mathrm{M}^{-1} \mathrm{~s}^{-1}\right)(21,91)$ than short, unstructured RNAs that bind near the diffusion-controlled limit $\left(\sim 10^{8} \mathrm{M}^{-1} \mathrm{~s}^{-1}\right)(83)$.

\section{Helix nucleation}

Although Hfq can promote sRNA-mRNA association by co-localizing and refolding the RNA, this RNA refolding activity of Hfq is not in itself sufficient to achieve maximum annealing rates (97). Biophysical experiments on DsrA sRNA and RNA oligomers revealed that Hfq accelerates base pairing between complementary RNAs, after the ternary complex has formed. For oligonucleotides, the rate of helix formation was 10-10,000 times faster with E. coli Hfq (83). Trapping intermediates with a photo-caged RNA indicated that Hfq stabilizes a helix initiation complex that base pairs rapidly once the protecting group is removed (85). Once base pairing is complete, Hfq cycles off the newly formed dsRNA (21), reducing the rate of the reverse reaction (unzippering) and freeing Hfq to interact with another substrate. These observations led to a working model for RNA annealing by E. coli Hfq, in which RNAs are initially recruited to Hfq through rapid binding to the rim and the proximal or distal face. Formation of the ternary complex is followed by slow helix nucleation, rapid zippering, and dsRNA release (Figure 2) $(39,83)$.

Replacing the rim arginines with alanine eliminates Hfq's annealing activity in these assays, although RNA binding to the proximal or distal faces is unaffected $(39,85)$. Exactly how these arginines facilitate RNA base pairing remains unclear. Basic residues on the rim and in the flexible NTDs interact with the RNA phosphate backbone $(45,102)$, which may reduce electrostatic repulsion between the two strands, in a manner similar to the RNA matchmaker protein gBP21 (103). Lysine residues are less active than arginines (39), raising the possibility that the arginine guanidinium group hydrogen bonds with the RNA base pairs. Interestingly, conserved acidic residues flanking the basic patch may be important for correctly orienting the seed and target RNAs at the active site (104). Finally, the geometry of the Hfq hexamer may alleviate the entropic penalty for helix initiation by restricting the conformations of natural RNA substrates (48). Although the rim arginines are essential for RNA annealing in vitro, it is not clear whether this activity of Hfq is always needed for sRNA regulation in the cell $(31,50)$.

\section{Product release}

When the Hfq concentration greatly exceeds the concentration of dsRNA, E. coli Hfq melts short dsRNA oligomers $(102,105)$ and sRNA-mRNA duplexes $(96)$, particularly when the duplex is unstable or A/U-rich. This destabilization of dsRNA suggests that rather than 
accelerate annealing by binding and stabilizing duplexes (106), the rim of Hfq may instead bind partially annealed or "frayed" reaction intermediates. Several mechanisms may work in concert to prevent Hfq from improperly destabilizing sRNA-mRNA complexes and disrupting sRNA regulation. For example, the total concentration of substrate RNA is normally high relative to Hfq in the cell (84), preventing Hfq from rebinding ternary complexes (91). As discussed below, the CTDs of Hfq also facilitate the release of dsRNA by competing for electrostatic interactions with Hfq rim residues $(32,40)$. Finally, coupled turnover of many sRNA-mRNA pairs $(9,31)$ prevents reversal of the regulatory signal and ensures a rapid recovery of mRNA activity once sRNA transcription is halted.

\section{Intrinsically disordered domains of $\mathrm{Hfq}$}

Like many RNA binding proteins (107), Hfq contains intrinsically disordered regions in addition to its stably folded Sm core domain (Figure 1A). In most bacterial Hfqs, disordered NTDs and CTDs protrude from the proximal face and rim of Hfq hexamers respectively (53, 54). Because each hexamer has 6 NTDs and CTDs, these disordered regions can stabilize or occlude RNA binding to the Hfq core (Figure 3A). Similar to disordered regions of other proteins (108-110), the NTD and CTD have diverged at a faster rate than the Sm core, via non-conservative substitutions and indels. This variability has made it more difficult to elucidate the function of the NTD and CTD. A recent model for the E. coli Hfq CTD (40) suggests how variations in these disordered regions fine-tune the function of Hfq in different bacterial genera.

The NTDs are typically short (mode of 4 residues), but range from 0-49 residues in length (Figure 1A). These flexible segments protrude from the proximal face of Hfq, which could allow even short NTDs to interact with RNA bound to this surface. Indeed, in the first cocrystal structure of an sRNA with Hfq, residues in the NTD of $E$. coli Hfq provide further stabilizing contacts with RNA bound at the rim of a neighboring monomer (45).

Furthermore, the basic, 15 residue NTD of Methanococcus jannaschii Hfq has been shown to bind RNAs (55). Nevertheless, additional studies are needed to determine the NTD's effects on sRNA and mRNA binding and annealing.

The typically longer CTDs range from 0-185 residues (mode of 9), and protrude from the rim of the Hfq hexamer (53) (Figure 3A). In $\gamma$-proteobacteria, the beginning of the CTD tends to pack along the core of Hfq, increasing the stability of the hexamer $(76,111)$. Nevertheless, most of the E. coli Hfq CTD is disordered in solution NMR (112) and small angle X-ray scattering $(54,112,113)$ experiments, and are unresolved in crystal structures.

\section{CTD autoinhibition}

The subtle and sometimes conflicting effects of the CTD on RNA binding (111, 115-117), annealing $(32,45,112,116)$ and sRNA-mediated post-transcriptional regulation $(32,45$, $115,118-120$ ) suggested to us that the CTD modulates the function of the Hfq Sm core, either as an autoregulator or by recruiting partner proteins in the cell (32). Biophysical assays for RNA binding and annealing, as well as genetic reporters in E. coli, showed that the 30 aa CTD of E. coli Hfq is not needed for RNA annealing (32). In fact, Hfq lacking the entire CTD anneals RNA more actively than full-length Hfq. In the full-length protein, the 
CTD restricts Hfq's chaperone activity by inhibiting non-specific ssRNA binding to the rim of the hexamer. In addition, the results of stopped-flow FRET and fluorescence anisotropy experiments showed that the CTD displaces dsRNA from the rim after annealing is complete. dsRNA was released from full-length Hfq in a few seconds, whereas dsRNA remained bound to Hfq lacking the CTD for many minutes.

Thus, the intrinsically disordered CTDs convert the stable Sm RNA binding domain of Hfq into a dynamic chaperone for RNA. In an updated model for Hfq's chaperone activity (32), the flexible CTDs continually sweep RNA from the rim and the proximal surface of the Sm ring (Figure 3B). Consequently, only RNAs that stably bind the proximal pore or distal face form long-lived ternary complexes. Once two complementary RNAs base pair, the CTDs displace the newly formed duplex from the rim of the hexamer, preventing strand separation and making the rim sites available for the next RNA.

\section{Nucleic acid mimicry}

Autoinhibition and dsRNA release are accomplished by transient interactions between the acidic ends of the CTDs and the basic patches on the rim of $\operatorname{Hfq}(32,40)$. This selfinteraction was consistent with NMR chemical shift anisotropy measurements on E. coli Hfq, which suggested that CTD residues transiently interact with residues on the rim of the hexamer (112). De novo modeling with ROSETTA and intermolecular binding of CTD peptides with the Hfq core showed that the acidic CTD tip competes with sRNA and DNA for binding to the basic patch. This competition prevents Hfq from binding RNA or DNA indiscriminately, which is likely important in the cell where many nucleic acids compete for a limited quantity of Hfq protein. Mimicry of nucleic acid by an acidic polypeptide is widespread in nucleic acid binding proteins, such as HTLV-1 NC (121), E. coli gyrase (122), SSB (123), and mammalian high-mobility group B1 (124).

\section{CTD-RNA interactions}

Although the E. coli Hfq CTD peptide does not measurably bind RNA on its own, the CTDs may stabilize certain RNA-Hfq complexes $(45,53,67)$, however the mechanism of stabilization is unknown. For example, several studies reported a modest decrease in binding affinity of sRNAs to Hfq in the absence of the CTD $(115,117)$, while the binding of short ssRNAs was unaffected and short dsRNAs was improved (32). We envision several explanations for apparent stabilization of RNA binding by the CTD. First, substrate RNAs $(45,51)$ and the Hfq CTDs $(40)$ both occupy large volumes around the Hfq core. This may limit the number of RNA segments that can simultaneously interact with the rim of the Hfq hexamer, while destabilizing low affinity, non-specific complexes. As a result, the remaining complexes are more uniform. Second, weak hydrogen bonding or aromatic stacking interactions between CTD residues and the RNA may only occur when the RNAs are tethered to the proximal or distal faces of Hfq. These interactions are likely to be transient, as regular folding of the CTD was not discerned in a co-crystal of RydC sRNA with Hfq (45). Although the CTDs were reported to increase the on-rate of RNA by surface plasmon resonance (45), no difference in on-rate was seen by stopped-flow FRET (32). Finally, it is uncertain that neutral or negatively charged CTDs of many Hfqs could attract RNA (40) by "fly-casting" or by other mechanisms (126).

Wiley Interdiscip Rev RNA. Author manuscript; available in PMC 2019 July 01. 


\section{Active cycling and sRNA competition}

Competition among sRNAs for access to Hfq determines the efficiency of sRNA regulation in the cell $(28,29)$. The number of Hfq hexamers in an E. coli cell ranges from 1,40010,000 , depending on the growth medium and the stage of the bacterial growth cycle. These estimates equate to an intracellular concentration of 2-15 $\mu \mathrm{M}$ Hfq hexamer, which is 5010,000 times greater than the dissociation constant of Hfq for most sRNA and mRNA substrates (127-129). RNA substrates are in turn estimated to be in large excess over Hfq (84). Therefore, all Hfq hexamers in the cell are thought to be bound to sRNA or mRNA, and surrounded by a large pool of additional, free RNA substrates $(28,29)$. Free sRNA is rapidly turned over by cellular ribonucleases, as evident from the decreased lifetimes of sRNAs in the absence of Hfq $(28,29,50,130,131)$. Thus, competition for Hfq also affects sRNA accumulation (28). However, the fraction of sRNA and mRNA-bound to Hfq in vivo has not been quantitatively determined, which would assist the examination of how regulatory networks rely on Hfq under different conditions.

Remarkably, newly synthesized sRNAs can rapidly gain access to saturated Hfq, such that sRNA-mediated degradation of an mRNA target is typically complete within 3-5 minutes of sRNA induction from its chromosomal locus (9), or a plasmid (132). Slower regulation has been reported for some sRNA-mRNA pairs, such as SgrS-dependent degradation of manX mRNA (133). Certain sRNA-mRNA pairs, such as SgrS-man $X$ or RyhB-sodB, may anneal independently of $\mathrm{Hfq}(92,134)$, but nevertheless rely on Hfq for sRNA stability (92) or downstream regulation (17).

\section{sRNA cycling}

Fast sRNA-mediated regulation demands that Hfq search out complementary sRNA-mRNA pairs among a large quantity of competitor RNA. This responsiveness seems at first inconsistent with the tight affinity of Hfq for its substrates, which can form long-lived $\left(\mathrm{t}_{1 / 2} \sim\right.$ $100 \mathrm{~min}) \mathrm{Hfq}-\mathrm{RNA}$ complexes in vitro $(91,135)$. This paradox is solved by the ability of sRNAs to actively cycle on and off $\mathrm{Hfq}(28,84,91,135,136)$. Active cycling, in which a free sRNA displaces one bound to Hfq, may be enabled by the multiple RNA binding surfaces on Hfq hexamers which can be shared by two or more RNAs $(48,84)$. By sweeping RNA from the proximal face and rim, the CTDs amplify sRNA competition and may drive active sRNA cycling (32).

\section{Hfq CTD heightens sRNA competition}

Variance in the kinetic competition between different sRNAs enables a more nuanced crosstalk between signaling pathways that regulate the same target, because sRNAs that do not bind Hfq are rapidly turned over. A strongly competing RNA can either gain access to Hfq when present in very low amounts relative to other RNA substrates, or can dominate Hfqdependent pathways when present at equimolar amounts. Biochemical (33) and in vivo competition experiments $(28,29)$ showed that sRNAs differ widely in their ability to compete for Hfq, although they have similar binding affinities. The broad hierarchy of competition indicates the importance of kinetic effects, such as active cycling, on sRNA regulation. 
At least one method for instituting a hierarchy of regulatory pathways through sRNA competition seems to have arisen via the co-evolution of sRNAs and the Hfq CTD. In $E$. coli, a minor group of sRNAs (Class II, see Box 2) often outcompete the more abundant Class I sRNAs. These Class II sRNAs contain AAN motifs as well as U-rich sequences, enabling them to bind both the distal and proximal faces of $\operatorname{Hfq}(31,33)$, resulting in increased accumulation of Class II sRNAs (31). Although the Hfq CTDs sweep RNA from the rim and proximal side of Hfq, AAN RNA bound to the distal face of Hfq is immune to this displacement (Figure 3B). As a result, the CTDs selectively destabilize Class I sRNAHfq interactions, while handing Class II sRNAs a competitive advantage $(32,40)$. Intriguingly, the CTD of E. coli $\mathrm{Hfq}$ is thought to have expanded concomitantly with the acquisition of new sRNAs (30).

\section{Search for complementary targets}

Finally, it is not enough that a given sRNA or mRNA successfully competes for Hfq; the same hexamer must also bind a cognate RNA for regulation to occur. How Hfq searches out cognate sRNA-mRNA pairs, which are greatly outnumbered by non-cognate pairs, is poorly understood at present. One proposition is that positive or a negative cooperativity in ternary complexes favors co-binding of cognate pairs, resulting in an increased efficiency of duplex formation between cognate pairs (137). However, there is currently little experimental support for cooperativity or anti-cooperativity in RNA binding. The fuzziness of trans-acting sRNA-target pairing may allow for the sampling and crystallization of new sRNA and mRNA binding sites (138), which can arise over relatively short timescales $(30,138)$. Finally, as outlined below, the structures of individual sRNA and mRNA substrates may increase the specificity of their base pairing interactions.

It has been proposed that high efficiency and robustness of duplex formation by Hfq could be achieved by a high rate of RNA dissociation, combined with a high rate of duplex release $(83,102,139,140)$. Increased RNA dissociation from Hfq is likely achieved via kinetic competition from additional substrate RNAs (84), enabled by the CTD (32). The importance of increased RNA dissociation and duplex release is thought to manifest in networks containing multiple sRNAs and mRNAs (137), such as that found in E. coli (18).

Nevertheless, many sRNA.Hfq.mRNA ternary complexes are known to be stable in vitro $(23,91,141)$. Perhaps the complementarity between these sRNA-mRNA pairs is unusually strong, or there may be annealing-dependent conformational changes that occur in the RNAs, which prevent the duplex from interacting with the rim again. The stability of certain ternary complexes is particularly important in some cases of negative regulation, in which RNase $\mathrm{E}$ is recruited for mRNA degradation $(12,142)$.

\section{Three-dimensional organization of ternary complexes}

sRNA-mRNA annealing involves not only the recruitment of cognate sRNA-mRNA pairs to the same ternary complex, but also the refolding of RNA substrates and the proper orientation of seed and target regions at nearby sites on the lateral rim of Hfq. The locations of $(\mathrm{AAN})_{\mathrm{X}}$ and U-rich Hfq binding motifs, plus the size and secondary structure of the RNA, dictates how a particular RNA folds around the Hfq hexamer. The architectures of Hfq-RNA

Wiley Interdiscip Rev RNA. Author manuscript; available in PMC 2019 July 01. 
complexes, which arise from the multiple RNA binding surfaces of the Hfq hexamer (51), may provide an additional layer of specificity for sRNA-mRNA recognition. Specific orientation of the RNA on Hfq is also likely important for interactions with downstream effectors such as the degradosome $(142,143)$, or co-recognition by other RNA-binding proteins $(66,144-146)$.

Proximal face binding sites on sRNAs are typically $3^{\prime}$ to the seed sequence, whereas distal face binding sites on mRNAs are typically $5^{\prime}$ to the target sequence (66). This organization poises the seed and target regions to find each other in the correct $5^{\prime}-3^{\prime}$ orientation at the arginine-rich rims of Hfq. It is not currently clear how this orientation is achieved for Class II sRNAs and their mRNA targets, especially as some mRNAs are regulated by both types of sRNA. Footprinting studies have shown that Hfq can restructure its mRNA targets, and these interactions may reorganize during sRNA annealing $(24,99,147)$. Interactions between single-stranded A/U-rich regions and RNA stem-loops to the rim of Hfq are particularly dynamic $(31,32,40,48,49,65)$. In the rpoS mRNA leader, Hfq binding to an upstream $(\mathrm{AAN})_{\mathrm{x}}$ motif and downstream U-rich loop folds the RNA into a more compact structure that strains the complementary target region, preparing it to base pair with incoming sRNA (51) (Figure 4). The multiplicity of interactions may be required for the coordination and folding of large substrates, such as $5^{\prime}$ mRNA leader sequences, around the Hfq core (51, 99).

\section{Conclusion}

Many recent advances have been made in understanding how the structured and disordered components of Hfq participate in RNA binding, competition and annealing. Structural and biochemical studies have started to shed light on how sRNAs and mRNAs contact the many RNA-binding surfaces of Hfq, and how multi-surface contacts lead to conformational strain or restructuring of large RNA substrates. Hfq's multiple RNA binding surfaces are necessary for the formation of ternary complexes, and are likely important for sRNA exchange. Fluorescence spectroscopy has revealed RNA substrate binding, annealing and product release to be a very dynamic process, in part mediated by competition from Hfq's disordered CTDs for RNA binding sites on the rim. Evolution of both the RNA substrates, as well as RNA binding and RNA competing segments of Hfq are relevant to the outcome of crosstalk between sRNA regulatory pathways in the cell.

Several gaps in the literature cry out for further experimentation. Firstly, high resolution structures of Hfq complexed with native sRNA or mRNA are key to understanding how RNA-protein contacts with the Hfq hexamer generate annealing-competent sRNA $\bullet H f q \cdot m R N A$ ternary complexes, given the symmetry of the Hfq hexamer. It is unknown how many rim sites are needed for Hfq's chaperone activity, and how nonproductive intermediates, in which the seed and target regions are positioned at opposite sides of the hexamer, are avoided. Single-molecule studies may assist in examining these questions.

Secondly, most RNA binding and annealing data is derived from observations with $E$. coli Hfq and closely related sequences. Further work is needed to know how substrate 
recognition, RNA competition, annealing speed and efficiency of product release differ among bacterial and archaeal Hfq proteins. Nevertheless, some trends can be anticipated from the concepts outlined in this review. For example, sequence and structural analyses of bacterial and archaeal Hfqs suggest that uridine recognition by the proximal pore is strongly conserved $(55,56,59,60)$, and likely to be maintained in most Hfqs. Whereas, the more variable distal face may have different binding partners in other species $(44,46,55,59,67$, 70-72). Similarly, the correspondence between annealing activity and the number of arginines in the basic patch (52) suggests that Hfq proteins lacking these arginines may have little chaperone activity, but instead participate in other aspects of RNA metabolism (5-9, 12-17, 92). Biochemical studies of E. coli Hfq CTD mutants and computational modelling of other Hfqs (40) suggest that short, acidic CTDs will strongly restrict RNA binding and annealing, whereas variants with flexible or less acidic CTDs will be more permissive chaperones. Competition for Hfq and turnover of free RNA enable a rapid response to new stressors in E. coli, but it is not known how these features are balanced in other organisms. Finally, there are now more examples in which Hfq acts together with another RNA binding protein $(66,146,148)$; how these proteins modify RNA recognition and sRNA-mRNA annealing is not yet understood.

\section{Acknowledgments}

The authors thank Jeliazko Jeliazkov for the Rosetta model of full-length Hfq-RydC. The authors' work on Hfq and sRNA was supported by a grant from the National Institutes of Health (R01 GM120425 to S.A.W.).

\section{References}

1. Franze de Fernandez MT, Eoyang L, August JT. Factor fraction required for the synthesis of bacteriophage Qbeta-RNA. Nature. 1968 Aug 10; 219(5154):588-90. [PubMed: 4874917]

2. Sun X, Zhulin I, Wartell RM. Predicted structure and phyletic distribution of the RNA-binding protein Hfq. Nucleic Acids Res. 2002 Sep 1; 30(17):3662-71. [PubMed: 12202750]

3. Valentin-Hansen P, Eriksen M, Udesen C. The bacterial Sm-like protein Hfq: a key player in RNA transactions. Mol Microbiol. 2004 Mar; 51(6):1525-33. [PubMed: 15009882]

4. Lybecker MC, Abel CA, Feig AL, Samuels DS. Identification and function of the RNA chaperone Hfq in the Lyme disease spirochete Borrelia burgdorferi. Mol Microbiol. 2010 Nov 01; 78(3):62235. [PubMed: 20815822]

5. Hajnsdorf E, Regnier P. Host factor Hfq of Escherichia coli stimulates elongation of poly(A) tails by poly(A) polymerase I. Proc Natl Acad Sci U S A. 2000 Feb 15; 97(4):1501-5. [PubMed: 10677490]

6. Le Derout J, Folichon M, Briani F, Deho G, Regnier P, Hajnsdorf E. Hfq affects the length and the frequency of short oligo(A) tails at the $3^{\prime}$ end of Escherichia coli rpsO mRNAs. Nucleic Acids Res. 2003 Jul 15; 31(14):4017-23. [PubMed: 12853618]

7. Sledjeski DD, Whitman C, Zhang A. Hfq is necessary for regulation by the untranslated RNA DsrA. J Bacteriol. 2001 Mar 01; 183(6):1997-2005. [PubMed: 11222598]

8. Moller T, Franch T, Hojrup P, Keene DR, Bachinger HP, Brennan RG, et al. Hfq: a bacterial Sm-like protein that mediates RNA-RNA interaction. Mol Cell. 2002 Jan; 9(1):23-30. [PubMed: 11804583]

9. Masse E, Escorcia FE, Gottesman S. Coupled degradation of a small regulatory RNA and its mRNA targets in Escherichia coli. Genes Dev. 2003 Oct 01; 17(19):2374-83. [PubMed: 12975324]

10. Zhang A, Wassarman KM, Ortega J, Steven AC, Storz G. The Sm-like Hfq protein increases OxyS RNA interaction with target mRNAs. Mol Cell. 2002 Jan; 9(1):11-22. [PubMed: 11804582]

11. Hammerle H, Beich-Frandsen M, Vecerek B, Rajkowitsch L, Carugo O, Djinovic-Carugo K, et al. Structural and biochemical studies on ATP binding and hydrolysis by the Escherichia coli RNA chaperone Hfq. PLoS One. 2012; 7(11):e50892. [PubMed: 23226421]

Wiley Interdiscip Rev RNA. Author manuscript; available in PMC 2019 July 01. 
12. Morita T, Maki K, Aiba H. RNase E-based ribonucleoprotein complexes: mechanical basis of mRNA destabilization mediated by bacterial noncoding RNAs. Genes Dev. 2005 Sep 15; 19(18): 2176-86. [PubMed: 16166379]

13. Pfeiffer V, Papenfort K, Lucchini S, Hinton JC, Vogel J. Coding sequence targeting by MicC RNA reveals bacterial mRNA silencing downstream of translational initiation. Nat Struct Mol Biol. 2009 Aug 01; 16(8):840-6. [PubMed: 19620966]

14. Chen J, Gottesman S. Hfq links translation repression to stress-induced mutagenesis in E. coli. Genes Dev. 2017 Aug 09.

15. Ellis MJ, Trussler RS, Haniford DB. Hfq binds directly to the ribosome-binding site of IS10 transposase mRNA to inhibit translation. Mol Microbiol. 2015 May 01; 96(3):633-50. [PubMed: 25649688]

16. Sonnleitner E, Blasi U. Regulation of Hfq by the RNA CrcZ in Pseudomonas aeruginosa carbon catabolite repression. PLoS Genet. 2014 Jun 19.10(6):e1004440. [PubMed: 24945892]

17. Desnoyers G, Masse E. Noncanonical repression of translation initiation through small RNA recruitment of the RNA chaperone Hfq. Genes Dev. 2012 Apr 01; 26(7):726-39. [PubMed: 22474262]

18. Wang J, Liu T, Zhao B, Lu Q, Wang Z, Cao Y, et al. sRNATarBase 3.0: an updated database for sRNA-target interactions in bacteria. Nucleic Acids Res. 2016 Jan 04.44(D1):248.

19. Mizuno T, Chou MY, Inouye M. A unique mechanism regulating gene expression: translational inhibition by a complementary RNA transcript (micRNA). Proc Natl Acad Sci U S A. 1984 Apr 01; 81(7):1966-70. [PubMed: 6201848]

20. Majdalani N, Cunning C, Sledjeski D, Elliott T, Gottesman S. DsrA RNA regulates translation of RpoS message by an anti-antisense mechanism, independent of its action as an antisilencer of transcription. Proc Natl Acad Sci U S A. 1998 Oct 13; 95(21):12462-7. [PubMed: 9770508]

21. Lease RA, Woodson SA. Cycling of the Sm-like Protein Hfq on the DsrA Small Regulatory RNA. J Mol Biol. 2004; 344(5):1211-23. [PubMed: 15561140]

22. Papenfort K, Vanderpool CK. Target activation by regulatory RNAs in bacteria. FEMS Microbiol Rev. 2015 May 01; 39(3):362-78. [PubMed: 25934124]

23. Soper TJ, Woodson SA. The rpoS mRNA leader recruits Hfq to facilitate annealing with DsrA sRNA. RNA. 2008 Sep 01; 14(9):1907-17. [PubMed: 18658123]

24. Soper T, Mandin P, Majdalani N, Gottesman S, Woodson SA. Positive regulation by small RNAs and the role of Hfq. Proc Natl Acad Sci U S A. 2010 May 25; 107(21):9602-7. [PubMed: 20457943]

25. Frohlich KS, Papenfort K, Fekete A, Vogel J. A small RNA activates CFA synthase by isoformspecific mRNA stabilization. EMBO J. 2013 Nov 13; 32(22):2963-79. [PubMed: 24141880]

26. De Lay N, Schu DJ, Gottesman S. Bacterial Small RNA-based Negative Regulation: Hfq and Its Accomplices. J Biol Chem. 2013 Mar 22; 288(12):7996-8003. [PubMed: 23362267]

27. Bossi L, Figueroa-Bossi N. Competing endogenous RNAs: a target-centric view of small RNA regulation in bacteria. Nat Rev Microbiol. 2016 Dec 01; 14(12):775-84. [PubMed: 27640758]

28. Moon K, Gottesman S. Competition among Hfq-binding small RNAs in Escherichia coli. Mol Microbiol. 2011 Dec; 82(6):1545-62. [PubMed: 22040174]

29. Hussein R, Lim HN. Disruption of small RNA signaling caused by competition for Hfq. Proc Natl Acad Sci U S A. 2011 Jan 18; 108(3):1110-5. [PubMed: 21189298]

30. Peer A, Margalit H. Evolutionary patterns of Escherichia coli small RNAs and their regulatory interactions. RNA. 2014 Jul; 20(7):994-1003. [PubMed: 24865611]

31. Schu DJ, Zhang A, Gottesman S, Storz G. Alternative Hfq-sRNA interaction modes dictate alternative mRNA recognition. EMBO J. 2015 Oct 14; 34(20):2557-73. [PubMed: 26373314]

32. Santiago-Frangos A, Kavita K, Schu DJ, Gottesman S, Woodson SA. C-terminal domain of the RNA chaperone Hfq drives sRNA competition and release of target RNA. Proc Natl Acad Sci U S A. 2016 Oct 11.113(41):E6096.

33. Malecka EM, Strozecka J, Sobanska D, Olejniczak M. Structure of bacterial regulatory RNAs determines their performance in competition for the chaperone protein Hfq. Biochemistry. 2015 Feb 10; 54(5):1157-70. [PubMed: 25582129]

Wiley Interdiscip Rev RNA. Author manuscript; available in PMC 2019 July 01. 
34. Gorski SA, Vogel J, Doudna JA. RNA-based recognition and targeting: sowing the seeds of specificity. Nat Rev Mol Cell Biol. 2017 Apr 01; 18(4):215-28. [PubMed: 28196981]

35. Butland G, Peregrin-Alvarez JM, Li J, Yang W, Yang X, Canadien V, et al. Interaction network containing conserved and essential protein complexes in Escherichia coli. Nature. 2005 Feb 03; 433(7025):531-7. [PubMed: 15690043]

36. Vogel J, Luisi BF. Hfq and its constellation of RNA. Nat Rev Microbiol. 2011 Aug 15; 9(8):57889. [PubMed: 21760622]

37. Sobrero P, Valverde C. The bacterial protein Hfq: much more than a mere RNA-binding factor. Crit Rev Microbiol. 2012 Nov 01; 38(4):276-99. [PubMed: 22435753]

38. Kavita K, de Mets F, Gottesman S. New aspects of RNA-based regulation by Hfq and its partner sRNAs. Curr Opin Microbiol. 2017 Nov 07.42:53-61. [PubMed: 29125938]

39. Panja S, Schu DJ, Woodson SA. Conserved arginines on the rim of Hfq catalyze base pair formation and exchange. Nucleic Acids Res. 2013 Aug; 41(15):7536-46. [PubMed: 23771143]

40. Santiago-Frangos A, Jeliazkov JR, Gray JJ, Woodson SA. Acidic C-terminal domains autoregulate the RNA chaperone Hfq. Elife. 2017 Aug 09.6doi: 10.7554/eLife.27049

41. Ward JJ, Sodhi JS, McGuffin LJ, Buxton BF, Jones DT. Prediction and functional analysis of native disorder in proteins from the three kingdoms of life. J Mol Biol. 2004 Mar 26; 337(3):635-45. [PubMed: 15019783]

42. Jones DT, Cozzetto D. DISOPRED3: precise disordered region predictions with annotated proteinbinding activity. Bioinformatics. 2015 Mar 15; 31(6):857-63. [PubMed: 25391399]

43. Wang W, Wang L, Zou Y, Zhang J, Gong Q, Wu J, et al. Cooperation of Escherichia coli Hfq hexamers in DsrA binding. Genes Dev. 2011 Oct 01; 25(19):2106-17. [PubMed: 21979921]

44. Link TM, Valentin-Hansen P, Brennan RG. Structure of Escherichia coli Hfq bound to polyriboadenylate RNA. Proc Natl Acad Sci U S A. 2009 Nov 17; 106(46):19292-7. [PubMed: 19889981]

45. Dimastrogiovanni D, Frohlich KS, Bandyra KJ, Bruce HA, Hohensee S, Vogel J, et al. Recognition of the small regulatory RNA RydC by the bacterial Hfq protein. Elife. 2014 Dec.31:3.doi: 10.7554/eLife.05375

46. Mikulecky PJ, Kaw MK, Brescia CC, Takach JC, Sledjeski DD, Feig AL. Escherichia coli Hfq has distinct interaction surfaces for DsrA, rpoS and poly(A) RNAs. Nat Struct Mol Biol. 2004 Dec; 11(12):1206-14. [PubMed: 15531892]

47. Otaka H, Ishikawa H, Morita T, Aiba H. PolyU tail of rho-independent terminator of bacterial small RNAs is essential for Hfq action. Proc Natl Acad Sci U S A. 2011 Aug 9; 108(32):13059_ 64. [PubMed: 21788484]

48. Sauer E, Schmidt S, Weichenrieder O. Small RNA binding to the lateral surface of Hfq hexamers and structural rearrangements upon mRNA target recognition. Proc Natl Acad Sci U S A. 2012 Jun 12; 109(24):9396-401. [PubMed: 22645344]

49. Ishikawa H, Otaka H, Maki K, Morita T, Aiba H. The functional Hfq-binding module of bacterial sRNAs consists of a double or single hairpin preceded by a U-rich sequence and followed by a $3^{\prime}$ poly(U) tail. RNA. 2012 May; 18(5):1062-74. [PubMed: 22454537]

50. Zhang A, Schu DJ, Tjaden BC, Storz G, Gottesman S. Mutations in interaction surfaces differentially impact E. coli Hfq association with small RNAs and their mRNA targets. J Mol Biol. 2013 Oct 9; 425(19):3678-97. [PubMed: 23318956]

51. Peng Y, Curtis JE, Fang X, Woodson SA. Structural model of an mRNA in complex with the bacterial chaperone Hfq. Proc Natl Acad Sci U S A. 2014 Dec 2; 111(48):17134-9. [PubMed: 25404287]

52. Zheng A, Panja S, Woodson SA. Arginine Patch Predicts the RNA Annealing Activity of Hfq from Gram-Negative and Gram-Positive Bacteria. J Mol Biol. 2016 Jun 05; 428(11):2259-64. [PubMed: 27049793]

53. Beich-Frandsen M, Vecerek B, Sjoblom B, Blasi U, Djinovic-Carugo K. Structural analysis of fulllength Hfq from Escherichia coli. Acta Crystallogr Sect F Struct Biol Cryst Commun. 2011 May 1.67:536-40.

Wiley Interdiscip Rev RNA. Author manuscript; available in PMC 2019 July 01. 
54. Vincent HA, Henderson CA, Ragan TJ, Garza-Garcia A, Cary PD, Gowers DM, et al. Characterization of Vibrio cholerae Hfq provides novel insights into the role of the Hfq C-terminal region. J Mol Biol. 2012 Jun 29; 420(1-2):56-69. [PubMed: 22484176]

55. Nikulin A, Mikhailina A, Lekontseva N, Balobanov V, Nikonova E, Tishchenko S. Characterization of RNA-binding properties of the archaeal Hfq-like protein from Methanococcus jannaschii. J Biomol Struct Dyn. 2017 Jun 01; 35(8):1615-28. [PubMed: 27187760]

56. Schumacher MA, Pearson RF, Moller T, Valentin-Hansen P, Brennan RG. Structures of the pleiotropic translational regulator $\mathrm{Hfq}$ and an Hfq-RNA complex: a bacterial Sm-like protein. EMBO J. 2002 Jul 1; 21(13):3546-56. [PubMed: 12093755]

57. Sauer E, Weichenrieder O. Structural basis for RNA $3^{\prime}$-end recognition by Hfq. Proc Natl Acad Sci U S A. 2011 Aug 09; 108(32):13065-70. [PubMed: 21737752]

58. Schulz EC, Barabas O. Structure of an Escherichia coli Hfq:RNA complex at 0.97 A resolution. Acta Crystallogr F Struct Biol Commun. 2014 Nov 01; 70(Pt 11):1492-7. [PubMed: 25372815]

59. Kovach AR, Hoff KE, Canty JT, Orans J, Brennan RG. Recognition of U-rich RNA by Hfq from the Gram-positive pathogen Listeria monocytogenes. RNA. 2014 Oct 01; 20(10):1548-59. [PubMed: 25150227]

60. Weichenrieder O. RNA binding by Hfq and ring-forming (L)Sm proteins: a trade-off between optimal sequence readout and RNA backbone conformation. RNA Biol. 2014; 11(5):537-49. [PubMed: 24828406]

61. Achsel T, Stark H, Luhrmann R. The Sm domain is an ancient RNA-binding motif with oligo(U) specificity. Proc Natl Acad Sci U S A. 2001 Mar 27; 98(7):3685-9. [PubMed: 11259661]

62. Thore S, Mayer C, Sauter C, Weeks S, Suck D. Crystal structures of the Pyrococcus abyssi Sm core and its complex with RNA. Common features of RNA binding in archaea and eukarya. J Biol Chem. 2003 Jan 10; 278(2):1239-47. [PubMed: 12409299]

63. Achsel T, Brahms H, Kastner B, Bachi A, Wilm M, Luhrmann R. A doughnut-shaped heteromer of human Sm-like proteins binds to the $3^{\prime}$-end of U6 snRNA, thereby facilitating U4/U6 duplex formation in vitro. EMBO J. 1999 Oct 15; 18(20):5789-802. [PubMed: 10523320]

64. Zhou L, Hang J, Zhou Y, Wan R, Lu G, Yin P, et al. Crystal structures of the Lsm complex bound to the $3^{\prime}$ end sequence of U6 small nuclear RNA. Nature. 2014 Feb 06; 506(7486):116-20. [PubMed: 24240276]

65. Tree JJ, Granneman S, McAteer SP, Tollervey D, Gally DL. Identification of bacteriophageencoded anti-sRNAs in pathogenic Escherichia coli. Mol Cell. 2014 Jul 17; 55(2):199-213. [PubMed: 24910100]

66. Holmqvist E, Wright PR, Li L, Bischler T, Barquist L, Reinhardt R, et al. Global RNA recognition patterns of post-transcriptional regulators Hfq and CsrA revealed by UV crosslinking in vivo. EMBO J. 2016 May 02; 35(9):991-1011. [PubMed: 27044921]

67. Robinson KE, Orans J, Kovach AR, Link TM, Brennan RG. Mapping Hfq-RNA interaction surfaces using tryptophan fluorescence quenching. Nucleic Acids Res. 2014 Feb; 42(4):2736-49. [PubMed: 24288369]

68. Senear AW, Steitz JA. Site-specific interaction of Qbeta host factor and ribosomal protein S1 with Qbeta and R17 bacteriophage RNAs. J Biol Chem. 1976 Apr 10; 251(7):1902-12. [PubMed: 773930]

69. de Haseth PL, Uhlenbeck OC. Interaction of Escherichia coli host factor protein with oligoriboadenylates. Biochemistry. 1980 Dec 23; 19(26):6138-46. [PubMed: 6162476]

70. Horstmann N, Orans J, Valentin-Hansen P, Shelburne SA, Brennan RG. Structural mechanism of Staphylococcus aureus Hfq binding to an RNA A-tract. Nucleic Acids Res. 2012 Nov 01; 40(21): 11023-35. [PubMed: 22965117]

71. Someya T, Baba S, Fujimoto M, Kawai G, Kumasaka T, Nakamura K. Crystal structure of Hfq from Bacillus subtilis in complex with SELEX-derived RNA aptamer: insight into RNA-binding properties of bacterial Hfq. Nucleic Acids Res. 2012 Feb 01; 40(4):1856-67. [PubMed: 22053080]

72. Nielsen JS, Boggild A, Andersen CB, Nielsen G, Boysen A, Brodersen DE, et al. An Hfq-like protein in archaea: crystal structure and functional characterization of the Sm protein from Methanococcus jannaschii. RNA. 2007 Dec 01; 13(12):2213-23. [PubMed: 17959927]

Wiley Interdiscip Rev RNA. Author manuscript; available in PMC 2019 July 01. 
73. Folichon M, Arluison V, Pellegrini O, Huntzinger E, Regnier P, Hajnsdorf E. The poly(A) binding protein Hfq protects RNA from RNase E and exoribonucleolytic degradation. Nucleic Acids Res. 2003 Dec 15; 31(24):7302-10. [PubMed: 14654705]

74. Moll I, Afonyushkin T, Vytvytska O, Kaberdin VR, Blasi U. Coincident Hfq binding and RNase E cleavage sites on mRNA and small regulatory RNAs. RNA. 2003 Nov 01; 9(11):1308-14. [PubMed: 14561880]

75. Stanek KA, Patterson-West J, Randolph PS, Mura C. Crystal structure and RNA-binding properties of an Hfq homolog from the deep-branching Aquificae: conservation of the lateral RNA-binding mode. Acta Crystallogr D Struct Biol. 2017 Apr 01; 73(Pt 4):294-315. [PubMed: 28375142]

76. Sauter C, Basquin J, Suck D. Sm-like proteins in Eubacteria: the crystal structure of the Hfq protein from Escherichia coli. Nucleic Acids Res. 2003; 31(14):4091-8. [PubMed: 12853626]

77. Nikulin A, Stolboushkina E, Perederina A, Vassilieva I, Blaesi U, Moll I, et al. Structure of Pseudomonas aeruginosa Hfq protein. Acta Crystallogr D Biol Crystallogr. 2005 Feb 01; 61(Pt 2): 141-6. [PubMed: 15681864]

78. Boggild A, Overgaard M, Valentin-Hansen P, Brodersen DE. Cyanobacteria contain a structural homologue of the Hfq protein with altered RNA-binding properties. FEBS J. 2009 Jul 01; 276(14): 3904-15. [PubMed: 19777643]

79. Arluison V, Derreumaux P, Allemand F, Folichon M, Hajnsdorf E, Regnier P. Structural Modelling of the Sm-like Protein Hfq from Escherichia coli. J Mol Biol. 2002 Jul 19; 320(4):705-12. [PubMed: 12095248]

80. Miranda G, Schuppli D, Barrera I, Hausherr C, Sogo JM, Weber H. Recognition of bacteriophage Qbeta plus strand RNA as a template by Qbeta replicase: role of RNA interactions mediated by ribosomal proteins S1 and host factor. J Mol Biol. 1997 Apr 18; 267(5):1089-103. [PubMed: 9150398]

81. Rajkowitsch L, Schroeder R. Coupling RNA annealing and strand displacement: a FRET-based microplate reader assay for RNA chaperone activity. BioTechniques. 2007 Sep.43(3):308. passim.

82. Kerwin SM. Nucleic Acids: Structures, Properties, and Functions By Victor A. Bloomfield, Donald M. Crothers, and Ignacio Tinoco, Jr., with contributions from John E. Hearst, David E. Wemmer, Peter A. Kollman, and Douglas H. Turner. University Science Books, Sausalito, CA. 2000. ix + 794ppabcxyzpp $17 \times 25$ cm. ISBN 0-935702-49-0. \$85.00. J Med Chem. 2000; 43(24):4721-2.

83. Hopkins JF, Panja S, Woodson SA. Rapid binding and release of Hfq from ternary complexes during RNA annealing. Nucleic Acids Res. 2011 Jul; 39(12):5193-202. [PubMed: 21378124]

84. Wagner EG. Cycling of RNAs on Hfq. RNA Biol. 2013 Apr; 10(4):619-26. [PubMed: 23466677]

85. Panja S, Paul R, Greenberg MM, Woodson SA. Light-Triggered RNA Annealing by an RNA Chaperone. Angew Chem Int Ed Engl. 2015 Jun 15; 54(25):7281-4. [PubMed: 25959666]

86. Kunne T, Swarts DC, Brouns SJ. Planting the seed: target recognition of short guide RNAs. Trends Microbiol. 2014 Feb 01; 22(2):74-83. [PubMed: 24440013]

87. Kawamoto H, Koide Y, Morita T, Aiba H. Base-pairing requirement for RNA silencing by a bacterial small RNA and acceleration of duplex formation by Hfq. Mol Microbiol. 2006 Aug 01; 61(4):1013-22. [PubMed: 16859494]

88. Balbontin R, Fiorini F, Figueroa-Bossi N, Casadesus J, Bossi L. Recognition of heptameric seed sequence underlies multi-target regulation by RybB small RNA in Salmonella enterica. Mol Microbiol. 2010 Oct; 78(2):380-94. [PubMed: 20979336]

89. Papenfort K, Bouvier M, Mika F, Sharma CM, Vogel J. Evidence for an autonomous $5^{\prime}$ target recognition domain in an Hfq-associated small RNA. Proc Natl Acad Sci U S A. 2010 Nov 23; 107(47):20435-40. [PubMed: 21059903]

90. Storz G, Opdyke JA, Zhang A. Controlling mRNA stability and translation with small, noncoding RNAs. Curr Opin Microbiol. 2004 Apr 01; 7(2):140-4. [PubMed: 15063850]

91. Fender A, Elf J, Hampel K, Zimmermann B, Wagner EG. RNAs actively cycle on the Sm-like protein Hfq. Genes Dev. 2010 Dec 1; 24(23):2621-6. [PubMed: 21123649]

92. Hao Y, Zhang ZJ, Erickson DW, Huang M, Huang Y, Li J, et al. Quantifying the sequence-function relation in gene silencing by bacterial small RNAs. Proc Natl Acad Sci U S A. 2011 Jul 26; 108(30):12473-8. [PubMed: 21742981]

Wiley Interdiscip Rev RNA. Author manuscript; available in PMC 2019 July 01. 
93. Moll I, Leitsch D, Steinhauser T, Blasi U. RNA chaperone activity of the Sm-like Hfq protein. EMBO Rep. 2003 Mar 01; 4(3):284-9. [PubMed: 12634847]

94. Geissmann TA, Touati D. Hfq, a new chaperoning role: binding to messenger RNA determines access for small RNA regulator. EMBO J. 2004 Jan 28; 23(2):396-405. [PubMed: 14739933]

95. Antal M, Bordeau V, Douchin V, Felden B. A small bacterial RNA regulates a putative ABC transporter. J Biol Chem. 2005 Mar 04; 280(9):7901-8. [PubMed: 15618228]

96. Arluison V, Hohng S, Roy R, Pellegrini O, Regnier P, Ha T. Spectroscopic observation of RNA chaperone activities of $\mathrm{Hfq}$ in post-transcriptional regulation by a small non-coding RNA. Nucleic Acids Res. 2007; 35(3):999-1006. [PubMed: 17259214]

97. Soper TJ, Doxzen K, Woodson SA. Major role for mRNA binding and restructuring in sRNA recruitment by Hfq. RNA. 2011 Aug; 17(8):1544-50. [PubMed: 21705431]

98. Jain, K., Updegrove, TB., Wartell, RM. Frontiers in Nucleic Acids. American Chemical Society; 2011. A Thermodynamic Perspective of sRNA-mRNA Interactions and the Role of Hfq; p. 111-31.

99. Bordeau V, Felden B. Curli synthesis and biofilm formation in enteric bacteria are controlled by a dynamic small RNA module made up of a pseudoknot assisted by an RNA chaperone. Nucleic Acids Res. 2014 Apr 01; 42(7):4682-96. [PubMed: 24489123]

100. Herschlag D, Khosla M, Tsuchihashi Z, Karpel RL. An RNA chaperone activity of non-specific RNA binding proteins in hammerhead ribozyme catalysis. EMBO J. 1994 Jun 15; 13(12):291324. [PubMed: 8026476]

101. Bertrand EL, Rossi JJ. Facilitation of hammerhead ribozyme catalysis by the nucleocapsid protein of HIV-1 and the heterogeneous nuclear ribonucleoprotein A1. EMBO J. 1994 Jun 15; 13(12): 2904-12. [PubMed: 8026475]

102. Hopkins JF, Panja S, McNeil SAN, Woodson SA. Effect of salt and RNA structure on annealing and strand displacement by Hfq. Nucleic Acids Res. 2009; 37(18):6205-13. [PubMed: 19671524]

103. Muller UF, Goringer HU. Mechanism of the gBP21-mediated RNA/RNA annealing reaction: matchmaking and charge reduction. Nucleic Acids Res. 2002 Jan 15; 30(2):447-55. [PubMed: 11788706]

104. Panja S, Santiago-Frangos A, Schu DJ, Gottesman S, Woodson SA. Acidic Residues in the Hfq Chaperone Increase the Selectivity of sRNA Binding and Annealing. J Mol Biol. 2015 Nov 6; 427(22):3491-500. [PubMed: 26196441]

105. Doetsch M, Stampfl S, Furtig B, Beich-Frandsen M, Saxena K, Lybecker M, et al. Study of E. coli Hfq's RNA annealing acceleration and duplex destabilization activities using substrates with different GC-contents. Nucleic Acids Res. 2013 Jan 07; 41(1):487-97. [PubMed: 23104381]

106. Crothers DM. Statistical thermodynamics of nucleic acid melting transitions with coupled binding equilibria. Biopolymers. 1971 Nov 01; 10(11):2147-60. [PubMed: 5118648]

107. Tompa P, Csermely P. The role of structural disorder in the function of RNA and protein chaperones. FASEB J. 2004 Aug; 18(11):1169-75. [PubMed: 15284216]

108. Liu J, Zhang Y, Lei X, Zhang Z. Natural selection of protein structural and functional properties: a single nucleotide polymorphism perspective. Genome Biol. 2008 Apr 08.9(4):r69. [PubMed: 18397526]

109. Brown CJ, Johnson AK, Daughdrill GW. Comparing models of evolution for ordered and disordered proteins. Mol Biol Evol. 2010 Mar 01; 27(3):609-21. [PubMed: 19923193]

110. Light S, Sagit R, Sachenkova O, Ekman D, Elofsson A. Protein expansion is primarily due to indels in intrinsically disordered regions. Mol Biol Evol. 2013 Dec 01; 30(12):2645-53. [PubMed: 24037790]

111. Arluison V, Folichon M, Marco S, Derreumaux P, Pellegrini O, Seguin J, et al. The C-terminal domain of Escherichia coli Hfq increases the stability of the hexamer. Eur J Biochem. 2004 Apr; 271(7):1258-65. [PubMed: 15030475]

112. Beich-Frandsen M, Vecerek B, Konarev PV, Sjoblom B, Kloiber K, Haemmerle H, et al. Structural insights into the dynamics and function of the C-terminus of the E. coli RNA chaperone Hfq. Nucleic Acids Res. 2011; 39(11):4900-15. [PubMed: 21330354]

Wiley Interdiscip Rev RNA. Author manuscript; available in PMC 2019 July 01. 
113. Kadowaki MA, Iulek J, Barbosa JA, de Pedrosa FO, de Souza EM, Chubatsu LS, et al. Structural characterization of the RNA chaperone Hfq from the nitrogen-fixing bacterium Herbaspirillum seropedicae SmR1. Biochim Biophys Acta. 2012 Feb 01; 1824(2):359-65. [PubMed: 22154803]

114. Conway P, Tyka MD, DiMaio F, Konerding DE, Baker D. Relaxation of backbone bond geometry improves protein energy landscape modeling. Protein Sci. 2014 Jan 01; 23(1):47-55. [PubMed: 24265211]

115. Sonnleitner E, Napetschnig J, Afonyushkin T, Ecker K, Vecerek B, Moll I, et al. Functional effects of variants of the RNA chaperone Hfq. Biochem Biophys Res Commun. 2004 Oct 22; 323(3):1017-23. [PubMed: 15381101]

116. Vecerek B, Rajkowitsch L, Sonnleitner E, Schroeder R, Blasi U. The C-terminal domain of Escherichia coli Hfq is required for regulation. Nucleic Acids Res. 2008 Jan; 36(1):133-43. [PubMed: 18000007]

117. Updegrove TB, Wartell RM. The influence of Escherichia coli Hfq mutations on RNA binding and sRNA*mRNA duplex formation in rpoS riboregulation. Biochim Biophys Acta. 2011 Oct; 1809(10):532-40. [PubMed: 21889623]

118. Sonnleitner E, Moll I, Blasi U. Functional replacement of the Escherichia coli hfq gene by the homologue of Pseudomonas aeruginosa. Microbiology. 2002 Mar.148:883-91. [PubMed: $11882724]$

119. Olsen AS, Moller-Jensen J, Brennan RG, Valentin-Hansen P. C-terminally truncated derivatives of Escherichia coli Hfq are proficient in riboregulation. J Mol Biol. 2010 Nov 26; 404(2):173-82. [PubMed: 20888338]

120. Salim NN, Faner MA, Philip JA, Feig AL. Requirement of upstream Hfq-binding (ARN)x elements in glmS and the Hfq C-terminal region for GlmS upregulation by sRNAs GlmZ and GlmY. Nucleic Acids Res. 2012 Sep; 40(16):8021-32. [PubMed: 22661574]

121. Qualley DF, Stewart-Maynard K, Wang F, Mitra M, Gorelick RJ, Rouzina I, et al. C-terminal domain modulates the nucleic acid chaperone activity of human T-cell leukemia virus type 1 nucleocapsid protein via an electrostatic mechanism. J Biol Chem. 2010 Jan 1; 285(1):295-307. [PubMed: 19887455]

122. Tretter EM, Berger JM. Mechanisms for defining supercoiling set point of DNA gyrase orthologs: I. A nonconserved acidic C-terminal tail modulates Escherichia coli gyrase activity. J Biol Chem. 2012 May 25; 287(22):18636-44. [PubMed: 22457353]

123. Kozlov AG, Cox MM, Lohman TM. Regulation of single-stranded DNA binding by the C termini of Escherichia coli single-stranded DNA-binding (SSB) protein. J Biol Chem. 2010 May 28; 285(22):17246-52. [PubMed: 20360609]

124. Watson M, Stott K, Thomas JO. Mapping intramolecular interactions between domains in HMGB1 using a tail-truncation approach. J Mol Biol. 2007 Dec 14; 374(5):1286-97. [PubMed: 17988686]

125. Doetsch M, Schroeder R, Furtig B. Transient RNA-protein interactions in RNA folding. FEBS J. 2011 May 01; 278(10):1634-42. [PubMed: 21410645]

126. Dogan J, Gianni S, Jemth P. The binding mechanisms of intrinsically disordered proteins. Phys Chem Chem Phys. 2014 Apr 14; 16(14):6323-31. [PubMed: 24317797]

127. Kajitani M, Kato A, Wada A, Inokuchi Y, Ishihama A. Regulation of the Escherichia coli hfq gene encoding the host factor for phage Q beta. J Bacteriol. 1994 Jan; 176(2):531-4. [PubMed: 8288550]

128. Ali Azam T, Iwata A, Nishimura A, Ueda S, Ishihama A. Growth phase-dependent variation in protein composition of the Escherichia coli nucleoid. J Bacteriol. 1999 Oct 01; 181(20):6361-70. [PubMed: 10515926]

129. Li GW, Burkhardt D, Gross C, Weissman JS. Quantifying absolute protein synthesis rates reveals principles underlying allocation of cellular resources. Cell. 2014 Apr 24; 157(3):624-35. [PubMed: 24766808]

130. Udekwu KI, Darfeuille F, Vogel J, Reimegard J, Holmqvist E, Wagner EG. Hfq-dependent regulation of OmpA synthesis is mediated by an antisense RNA. Genes Dev. 2005 Oct 1; 19(19): 2355-66. [PubMed: 16204185]

Wiley Interdiscip Rev RNA. Author manuscript; available in PMC 2019 July 01. 
131. Chao Y, Papenfort K, Reinhardt R, Sharma CM, Vogel J. An atlas of Hfq-bound transcripts reveals $3^{\prime}$ UTRs as a genomic reservoir of regulatory small RNAs. EMBO J. 2012 Oct 17; 31(20):4005-19. [PubMed: 22922465]

132. Papenfort K, Pfeiffer V, Mika F, Lucchini S, Hinton JC, Vogel J. SigmaE-dependent small RNAs of Salmonella respond to membrane stress by accelerating global omp mRNA decay. Mol Microbiol. 2006 Dec 01; 62(6):1674-88. [PubMed: 17427289]

133. Fei J, Singh D, Zhang Q, Park S, Balasubramanian D, Golding I, et al. Determination of in vivo target search kinetics of regulatory noncoding RNA. Science. 2015 Mar 20; 347(6228):1371-4. [PubMed: 25792329]

134. Azam MS, Vanderpool CK. Translational regulation by bacterial small RNAs via an unusual Hfqdependent mechanism. Nucleic Acids Res. 2017 Dec 23.

135. Olejniczak M. Despite similar binding to the Hfq protein regulatory RNAs widely differ in their competition performance. Biochemistry. 2011 May 31; 50(21):4427-40. [PubMed: 21510661]

136. Salim NN, Feig AL. An upstream Hfq binding site in the fhlA mRNA leader region facilitates the OxyS-fhlA interaction. PLoS One. 2010 Sep 28.5(9)doi: 10.1371/journal.pone.0013028

137. Adamson DN, Lim HN. Essential requirements for robust signaling in Hfq dependent small RNA networks. PLoS Comput Biol. 2011 Aug 01.7(8):e1002138. [PubMed: 21876666]

138. Updegrove TB, Shabalina SA, Storz G. How do base-pairing small RNAs evolve? FEMS Microbiol Rev. 2015 May 01; 39(3):379-91. [PubMed: 25934120]

139. Rajkowitsch L, Chen D, Stampfl S, Semrad K, Waldsich C, Mayer O, et al. RNA chaperones, RNA annealers and RNA helicases. RNA Biol. 2007 Nov 01; 4(3):118-30. [PubMed: 18347437]

140. Hwang W, Arluison V, Hohng S. Dynamic competition of DsrA and rpoS fragments for the proximal binding site of Hfq as a means for efficient annealing. Nucleic Acids Res. $2011 \mathrm{Jul} 01$; 39(12):5131-9. [PubMed: 21357187]

141. Rasmussen AA, Johansen J, Nielsen JS, Overgaard M, Kallipolitis B, Valentin-Hansen P. A conserved small RNA promotes silencing of the outer membrane protein YbfM. Mol Microbiol. 2009 May; 72(3):566-77. [PubMed: 19400782]

142. Ikeda Y, Yagi M, Morita T, Aiba H. Hfq binding at RhlB-recognition region of RNase E is crucial for the rapid degradation of target mRNAs mediated by sRNAs in Escherichia coli. Mol Microbiol. 2011 Jan; 79(2):419-32. [PubMed: 21219461]

143. Bandyra KJ, Said N, Pfeiffer V, Gorna MW, Vogel J, Luisi BF. The seed region of a small RNA drives the controlled destruction of the target mRNA by the endoribonuclease RNase E. Mol Cell. 2012 Sep 28; 47(6):943-53. [PubMed: 22902561]

144. Baker CS, Eory LA, Yakhnin H, Mercante J, Romeo T, Babitzke P. CsrA inhibits translation initiation of Escherichia coli hfq by binding to a single site overlapping the Shine-Dalgarno sequence. J Bacteriol. 2007 Aug 01; 189(15):5472-81. [PubMed: 17526692]

145. Jorgensen MG, Thomason MK, Havelund J, Valentin-Hansen P, Storz G. Dual function of the McaS small RNA in controlling biofilm formation. Genes Dev. 2013 May 15; 27(10):1132-45. [PubMed: 23666921]

146. Sonnleitner E, Wulf A, Campagne S, Pei XY, Wolfinger MT, Forlani G, et al. Interplay between the catabolite repression control protein $\mathrm{Crc}$, Hfq and RNA in Hfq-dependent translational regulation in Pseudomonas aeruginosa. Nucleic Acids Res. 2017 Dec 13.

147. Geissmann TA, Touati D. Hfq, a new chaperoning role: binding to messenger RNA determines access for small RNA regulator. EMBO J. 2004 Jan 28; 23(2):396-405. [PubMed: 14739933]

148. Potts AH, Vakulskas CA, Pannuri A, Yakhnin H, Babitzke P, Romeo T. Global role of the bacterial post-transcriptional regulator $\mathrm{CsrA}$ revealed by integrated transcriptomics. Nat Commun. 2017 Nov 17.8(1):1. [PubMed: 28232747]

Wiley Interdiscip Rev RNA. Author manuscript; available in PMC 2019 July 01. 
A

$$
\text { A }
$$
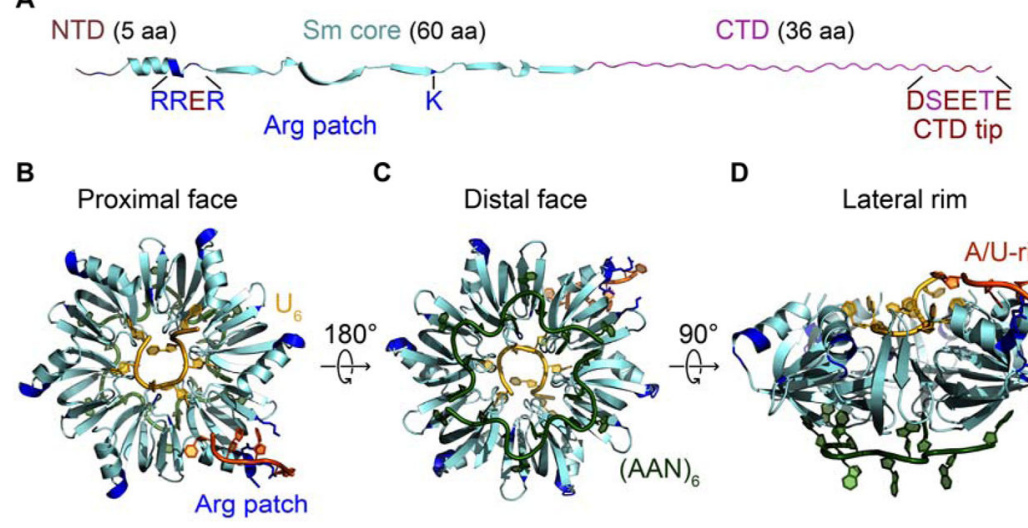

C Distal face

D Lateral rim

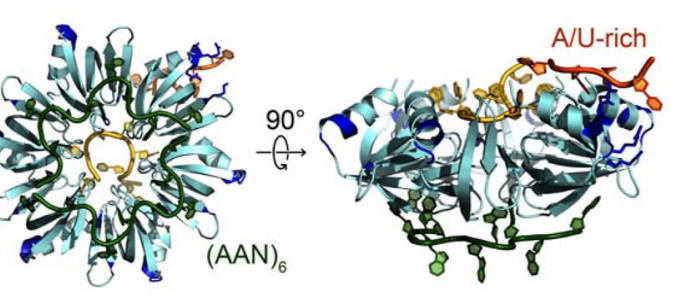

Figure 1. Structure and RNA binding surfaces of Hfq

(A) Secondary structure of E. coli Hfq, showing the ordered Sm core (cyan) with arginine patch (blue) necessary for annealing (39). Unstructured N-terminal (NTD; dark violet) and C-terminal (CTD; violet) domains are indicated schematically with the autoregulatory acidic CTD tip (40) in red. A previously described set of 985 non-redundant bacterial Hfq sequences $(40)$ were analyzed by DISOPRED $(41,42)$ to estimate the range of NTD (0-49 aa) and CTD (0-185 aa) lengths. (B-D) Superposition of crystal structures of Hfq bound to RNA oligomers. (B) Proximal face U-rich RNA (yellow) bound to inner pore (3RER; (43)). (C) Distal face bound to A18 RNA (green) (3GIB; (44)). (D) View of lateral rim (4V2S; (45)) with A/U-rich RNA (orange) bound to the outer edge of the proximal side.

Wiley Interdiscip Rev RNA. Author manuscript; available in PMC 2019 July 01. 


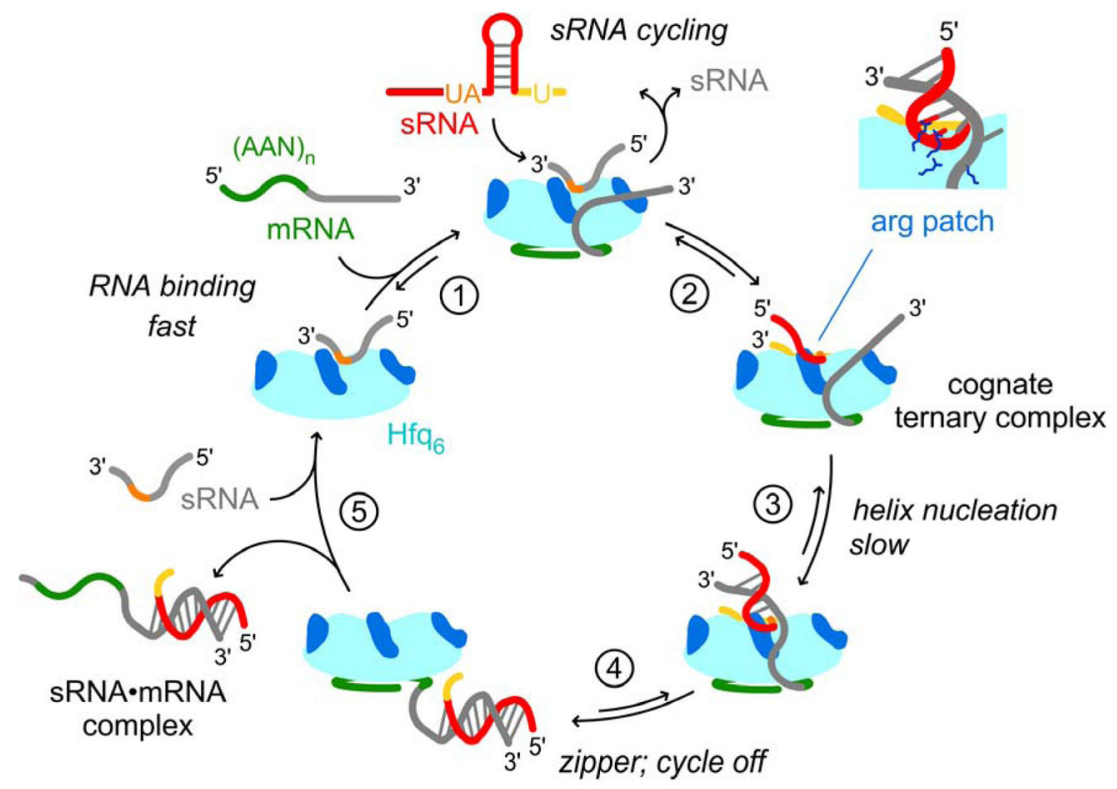

Figure 2. Cycle of RNA binding, annealing and release from Hfq

A working model for RNA annealing by E. coli Hfq. [1] sRNA (red) and mRNA (green and gray) rapidly bind the Hfq hexamer in random order to form ternary complexes. Short RNAs bind near the diffusion-controlled limit (83); longer RNAs that change structure bind more slowly. Non-cognate ternary complexes are unstable due to active cycling of excess Class I sRNAs on the proximal face of the hexamer (84), until [2] a cognate sRNA eventually binds to form a cognate ternary complex. [3] In the slow step of the reaction, nucleation of a helix between complementary regions of the sRNA and mRNA is facilitated by arginine-rich patches on the rim of the hexamer (blue). [4] Remaining base pairs rapidly zipper into a fully annealed sRNA·mRNA pair (85). CTDs efficiently displace dsRNA from the argininerich patches, preventing destabilization of the annealed segment $(32,40)$. [5] sRNA cycling, recruitment of a new mRNA or Class II sRNA, or RNase E turnover, may assist complete dissociation of annealed sRNA.mRNA complex from Hfq core. Hfq NTDs and CTDs are omitted from the pictograms for clarity.

Wiley Interdiscip Rev RNA. Author manuscript; available in PMC 2019 July 01. 

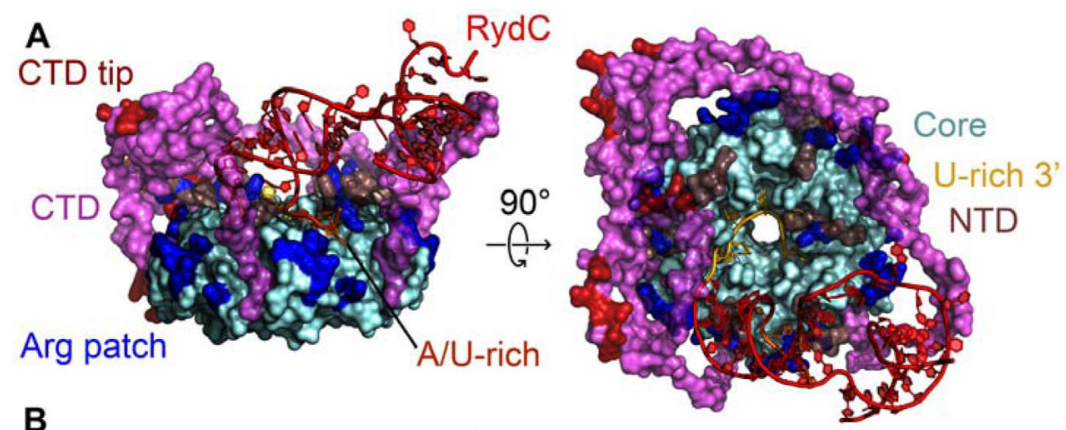

B sRNA competition

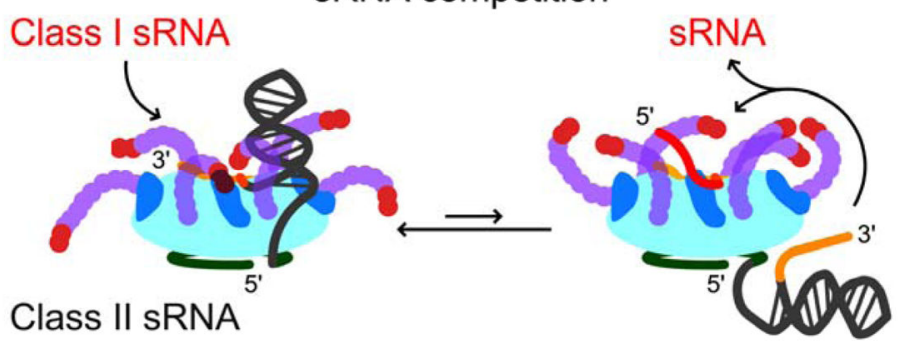

Figure 3. Binding of CTD to rim drives kinetic competition between sRNAs

(A) Model of Class I sRNA RydC (red cartoon) bound to full-length Hfq. Crystallographic structure of RydC-Hfq complex (4VQS; (45)) was superimposed on a ROSETTA model of full-length Hfq (40). Clashes introduced by the superposition were alleviated by gradientbased energy minimization and side-chain repacking with backbone coordinates kept constant (114). Shown is only one possible model for the flexible CTDs (violet shades), which can also sample the space on the distal side of the Hfq ring. Basic residues in the core and acidic residues in the CTD tip are colored blue and red, respectively. Some arginine patches are inaccessible due to electrostatic interactions with acidic CTD tips (40). The Utail of RydC (gold) binds the inner proximal pore, while an A/U-rich motif upstream of the terminal stem-loop interacts with the arginine-rich patch $(45,48,49)$. The body of RydC sRNA may weakly interact with the CTDs (45). (B) Class II sRNAs outcompete Class I sRNAs for access to Hfq, despite having similar binding affinities $(31,33)$. Class I sRNAs bind the proximal face and rim (31), and are readily displaced by acidic CTD tips $(32,40)$. Class II sRNAs contain an AAN motif (green) that binds the distal face (50) and resists displacement by CTDs, leading to a hierarchy of sRNA competition for binding to Hfq (32, 40). 
A

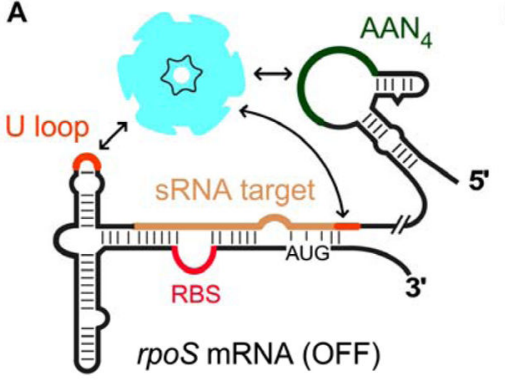

B

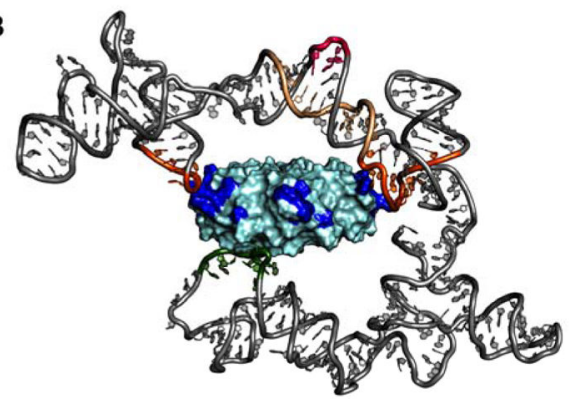

Figure 4. Hfq springloads $r p o S$ mRNA for sRNA entry

(A) The long (572 nt) leader of $r p o S$ mRNA contains Hfq binding motifs upstream (green) and downstream (gold) of the sRNA binding site (tan), which are necessary for sRNA regulation of $r p o S$ translation $(23,51)$. (B) SHAPE footprinting and SAXS showed that $r p o S$ mRNA contacts every RNA binding surface of Hfq, wrapping the RNA into a compact conformation that partially unwinds the sRNA target site and facilitates base-pairing with complementary sRNAs (51). Hfq NTDs and CTDs are omitted for clarity. 